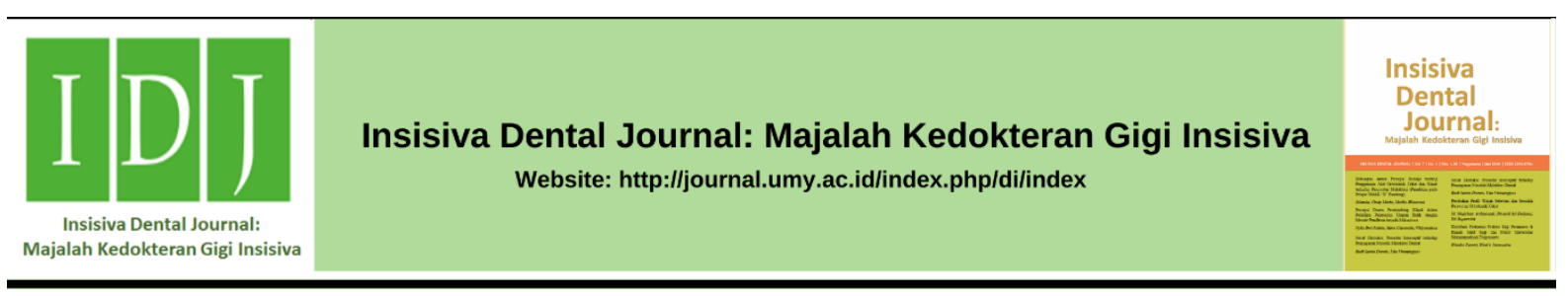

Research Article

\title{
Pengaruh Kebiasaan Buruk Oral terhadap Malrelasi Gigi pada Anak Panti Asuhan Usia 7-13 Tahun
}

\author{
Effect of Bad Oral Habit to Tooth Mal-Relation in Orphan Children Aged 7-13 Years
}

\section{Trianita Lydianna*, Desi Utari}

Departemen Kedokteran Gigi Anak, Program Studi Kedokteran Gigi, Fakultas Kedokteran dan Ilmu Kesehatan, Universitas Muhammadiyah Yogyakarta, Jalan Brawijaya, Tamantirto, Kasihan, Bantul, Daerah Istimewa Yogyakarta 55183, Indonesia.

Received date: September $23^{\text {rd }}, 2021$; revised date: November $18^{\text {th }}, 2021$; accepted: November $21^{\text {st }}, 2021$

DOI: $10.18196 /$ di.v10i1.12796

\begin{abstract}
Abstrak
Pertumbuhan dan perkembangan gigi anak turut dipengaruhi oleh pertumbuhan dan perkembangan fisik serta mental anak. Kebiasaan buruk oral merupakan suatu kebiasaan yang ditandai dengan durasi sedikitnya enam jam sehari dan dapat menyebabkan malrelasi gigi apabila frekuensi dan intensitasnya cukup tinggi. Anak yang tidak memiliki orangtua atau keluarga, atau tinggal di panti asuhan biasanya kurang mendapatkan kasih sayang yang cukup. Munculnya kebiasaan buruk oral merupakan salah satu cara mereka untuk mendapatkan kenyamanan. Penelitian ini bertujuan untuk melihat pengaruh kebiasaan buruk oral terhadap malrelasi gigi pada anak usia 7-13 tahun yang tinggal di Panti Asuhan Nurul Haq Yogyakarta. Desain penelitian ini adalah observasional analitik dengan pendekatan cross-sectional. Sebanyak 26 anak dilakukan pemeriksaan untuk melihat relasi giginya, kemudian dilakukan wawancara mendalam, dan pencetakan rahang. Data dianalisis menggunakan uji chi-square. Prevalensi mengisap ibu jari sebesar 30.7\%; menggigit jari sebesar 11.5\%; menggigit kuku, bibir, prolonged bottle-feeding, dan bruxism sebesar 7.7\%; dan bernapas lewat mulut 3.8\%. Prevalensi protrusi sebesar $23.1 \%$; open bite sebesar 15.4\%; deep bite sebesar 11.5\%; dan cross bite sebesar 7.7\%. Signifikansi nilai uji chi-square sebesar $0.008(\mathrm{p}<0.05)$. Kesimpulan dari hasil penelitian ini adalah terdapat pengaruh kebiasaan buruk oral terhadap malrelasi gigi pada anak panti asuhan usia 7-13 tahun.
\end{abstract}

Kata Kunci: Anak; Kebiasaan Buruk; Malrelasi Gigi

\begin{abstract}
The dental growth and development of children are influenced by their physical and mental growth and development. The bad oral habit is indicated by at least six hours per day and leads to tooth mal-relation due to high frequency and intensity. The children who did not have parents or any family or relatives used to be called orphans usually feel a lack of affirmation. The bad oral habit is one of their ways to find comfort. This study aims to analyze the effect of bad oral habits on tooth mal-relation in orphan children aged 7-13 years who live in Panti Asuhan Nurul Haq Yogyakarta. Data were collected by anamnesis, in-depth interview, clinical examination, and tooth impression in 26 orphan children aged 7-13 years. Observational analysis and chi-square tests were performed. Prevalence of thumb sucking was 30.7\%; finger biting was 11.5\%; nail-biting, lip biting, prolonged bottle feeding, and bruxism were 7.7\%; and mouth breathing was 3.8\%. Meanwhile, protrusion prevalence was $23.1 \%$; open bite was $15.4 \%$; deep bite was $11.5 \%$, and crossbite was $7.7 \%$. The chi-square test showed a 0.008 p-value ( $p<0.05)$, which indicated a significant result. Based on this study's findings, there were effects of bad oral habits on tooth mal-relation in orphan children aged 7-13 years.
\end{abstract}

Keywords: Bad Oral Habits; Child; Tooth Mal-relation

* Corresponding author, e-mail: lydiannafahmi@gmail.com 


\section{PENDAHULUAN}

Pertumbuhan dan perkembangan gigi anak bersifat individual dan dipengaruhi oleh pertumbuhan dan perkembangan anak secara umum. ${ }^{-}$ Kebiasaan buruk yang terjadi saat usia tumbuh kembang dapat memberikan efek destruktif pada struktur alveolar. Tiga faktor penting yang dapat memengaruhi keparahan pertumbuhan gigi-geligi seperti frekuensi (seberapa sering kebiasaan buruk terulang setiap harinya), durasi (seberapa lama kebiasaan buruk telah dilakukan) dan intensitas (seberapa besar tekanan yang anak lakukan) dapat menghasilkan efek yang merugikan dalam waktu yang lama. ${ }^{2}$ Anak yang berada pada periode gigi bercampur memiliki kerentanan terhadap terjadinya gigi berjejal dan maloklusi. Keparahan maloklusi dapat sangat terlihat pada usia gigi bercampur karena tahap tersebut merupakan masa terpenting dalam pertumbuhan dan perkembangan gigi anak. $\underline{3}$

Kebiasaan merupakan suatu pola perilaku yang berulang dan secara normal mengiringi perkembangan individu. ${ }^{4}$ Perilaku dapat dipengaruhi oleh lingkungan dan situasi di mana individu tersebut berada. Perilaku dapat berubah menjadi suatu kebiasaan buruk apabila seorang individu dihadapkan pada kondisi tidak menyenangkan dan berusaha mencari kompensasinya..$^{-}$Kebiasaan buruk oral biasanya terjadi pada anak usia di bawah enam tahun dan akan menghilang sebelum anak berusia enam tahun. Apabila kebiasaan berlanjut hingga lebih dari usia enam tahun maka dapat menyebabkan gangguan tumbuh kembang dentofasial. ${ }^{6}$ Perilaku ini berisiko menimbulkan maloklusi dan malrelasi gigi jika durasinya minimal enam jam sehari dan memiliki frekuensi dan intensitas yang tinggi. Malrelasi gigi diartikan sebagai kesalahan hubungan antara gigi-geligi pada rahang yang berbeda. Keadaan ini dapat mencetuskan terjadinya maloklusi. ${ }^{7}$

Beberapa contoh kebiasaan buruk oral di antaranya adalah mengisap ibu jari, bernapas lewat mulut, menggigit bibir ataupun $\mathrm{kuku}^{8}$, bruxism, dan prolonged bottle-feeding. ${ }^{9}$ Anak-anak yang tinggal di panti asuhan cenderung memiliki perilaku mengisap ibu jari lebih tinggi daripada anak yang diasuh dalam keluarga. Perilaku ini dapat terjadi karena situasi kelaparan atau ketakutan yang dihadapi oleh anak. Penyebab lainnya adalah karena rasa bosan, cemas, ataupun stres sehingga emosi anak turut terpengaruh dan mereka mengisap ibu jari sebagai salah satu bentuk pelampiasan. $\frac{10}{}$ Tujuan dari penelitian ini adalah untuk melihat pengaruh kebiasaan buruk oral terhadap malrelasi gigi pada anak panti asuhan usia 7-13 tahun.

\section{MATERIAL DAN METODE}

Penelitian observasional analitik ini dilakukan pada anak-anak yang tinggal di Panti Asuhan Nurul Haq Yogyakarta. Pengambilan sampel dilakukan dengan total sampling dan didapatkan sebanyak 26 anak yang memenuhi kriteria inklusi berupa usia 7-13 tahun dan bersedia menjadi responden. Informed consent diberikan dan ditandatangani oleh pengasuh panti asuhan sebagai wali dari para responden, sebagai bentuk persetujuan untuk berpartisipasi dalam penelitian ini.

Para responden dan pengasuhnya diwawancarai secara mendalam terkait kebiasaan buruk oral yang mungkin mereka alami. Kebiasaan buruk oral yang dialami oleh responden kemudian dikonfirmasi dengan pengamatan terhadap kebiasaan responden saat sedang tidak melakukan kegiatan atau saat sedang diam. Pemeriksaan intraoral dilakukan kepada para responden untuk melihat kondisi jaringan keras dan jaringan lunak, serta keadaan klinis di sekitar area bibir. Pemeriksaan ekstraoral juga dilakukan pada jari-jari tangan responden, untuk melihat bekas pola isapan atau gigitan pada jari maupun kuku. Durasi dan frekuensi kebiasaan buruk oral tidak dinilai dalam penelitian ini.

Pencetakan gigi-geligi para responden kemudian dilakukan untuk 
memeriksa malrelasi gigi yang terjadi. Penentuan kriteria malrelasi dilihat dari inklinasi gigi-geligi, besarnya overjet dan overbite, ada tidaknya gigitan silang atau gigitan terbuka, serta ada tidaknya area insisal dan oklusal gigi-geligi yang terkikis. Data kemudian dianalisis menggunakan uji chi-square. Nilai $\mathrm{p}<0.05$ diartikan sebagai hasil yang bermakna.

\section{HASIL}

Jumlah responden yang masuk dalam kriteria inklusi dan terlibat dalam penelitian ini adalah sebanyak 26 anak. Distribusi jumlah anak berdasarkan usia tersaji dalam tabel 1 .

Tabel 1. Distribusi jumlah anak berdasarkan usia

\begin{tabular}{lll}
\hline Usia & $\mathbf{n}$ & $\mathbf{\%}$ \\
\hline 7 & 1 & 3,8 \\
9 & 3 & 11,5 \\
10 & 6 & 23,1 \\
11 & 5 & 19,2 \\
12 & 9 & 34,6 \\
13 & 2 & 7,7 \\
\hline Total & $\mathbf{2 6}$ & $\mathbf{1 0 0}$ \\
\hline
\end{tabular}

Tabel 1 menunjukkan bahwa kelompok usia dengan jumlah terbanyak adalah anak usia 12 tahun sebanyak sembilan anak (34,6\%). Selanjutnya prevalensi kebiasaan buruk oral berdasarkan kelompok umur tersaji dalam tabel 2.

Tabel 2. Prevalensi kebiasaan buruk oral berdasarkan usia anak

\begin{tabular}{ccccccc}
\hline \multirow{2}{*}{ Usia } & \multicolumn{3}{c}{ Kebiasaan Buruk Oral } & \multicolumn{2}{c}{ Tidak } \\
\cline { 2 - 5 } & \multicolumn{2}{c}{ Ada } & \multicolumn{2}{c}{ Tidak ada } & \multicolumn{2}{c}{ Total } \\
\cline { 2 - 6 } & $\mathbf{n}$ & $\mathbf{\%}$ & $\mathbf{n}$ & $\mathbf{\%}$ & $\mathbf{n}$ & $\mathbf{\%}$ \\
\hline 7 & 0 & 0 & 1 & 3,8 & 1 & 3,8 \\
9 & 3 & 11,5 & 0 & 0 & 3 & 11,5 \\
10 & 3 & 11,5 & 3 & 11,5 & 6 & 23,1 \\
11 & 3 & 11,5 & 2 & 7,7 & 5 & 19,2 \\
12 & 6 & 23 & 3 & 11,5 & 9 & 34,6 \\
13 & 2 & 7,7 & 0 & 0 & 2 & 7,7 \\
\hline Total & $\mathbf{1 7}$ & $\mathbf{6 5 , 2}$ & $\mathbf{9}$ & $\mathbf{3 4 , 5}$ & $\mathbf{2 6}$ & $\mathbf{1 0 0}$ \\
\hline
\end{tabular}

Tabel 2 memberi gambaran bahwa kebiasaan buruk oral paling banyak terjadi pada anak kelompok usia 12 tahun sebanyak enam anak (23\%). Distribusi jenis kebiasaan buruk pada anak tersaji dalam tabel 3 .

Tabel 3. Distribusi jenis kebiasaan buruk oral pada anak

\begin{tabular}{ccccc}
\hline Kebiasaan buruk & \multicolumn{2}{c}{ Ada } & \multicolumn{2}{c}{ Tidak ada } \\
oral & n & $\%$ & n & \% \\
\hline $\begin{array}{c}\text { Bernafas dengan } \\
\text { mulut }\end{array}$ & 1 & 3,8 & 25 & 96,2 \\
Menggigit jari & 3 & 11,5 & 23 & 88,5 \\
Menggigit kuku & 2 & 7,7 & 24 & 92,3 \\
Menggigit bibir & 2 & 7,7 & 24 & 92,3 \\
Mengisap ibu jari & 8 & 30,7 & 18 & 69,2 \\
$\begin{array}{c}\text { Prolonged bottle- } \\
\text { feeding }\end{array}$ & 2 & 7,7 & 24 & 92,3 \\
Bruxism & 2 & 7,7 & 24 & 92,3 \\
\hline
\end{tabular}

Tabel 3 menunjukkan bahwa kebiasaan buruk oral yang paling banyak dialami adalah mengisap ibu jari sebanyak delapan anak (30,7\%). Selanjutnya distribusi jenis malrelasi gigi pada anak tersaji dalam tabel 4.

Tabel 4. Distribusi jenis malrelasi gigi pada anak

\begin{tabular}{ccccc}
\hline & \multicolumn{2}{c}{ Ada } & \multicolumn{2}{c}{ Tidak ada } \\
Tanda Klinis & $\mathbf{n}$ & $\mathbf{\%}$ & $\mathbf{n}$ & $\%$ \\
\hline Open bite & 4 & 15,4 & 22 & 84,6 \\
Edge to edge & 1 & 3,8 & 25 & 96,2 \\
Protrusif & 6 & 23,1 & 20 & 76,9 \\
Deep bite & 3 & 11,5 & 23 & 88,5 \\
Cross bite & 2 & 7,7 & 24 & 92,3 \\
Malposisi & 1 & 3,8 & 25 & 96,2 \\
Atrisi & 2 & 7,7 & 24 & 92,3 \\
\hline
\end{tabular}

Tabel 4 menggambarkan malrelasi yang paling banyak terjadi yaitu protrusif dengan jumlah enam anak $(23,1 \%)$. Hasil uji statistik pengaruh kebiasaan buruk oral terhadap malrelasi gigi tersaji dalam tabel 5 .

Tabel 5. Pengaruh kebiasaan buruk oral terhadap malrelasi gigi

\begin{tabular}{ccccc}
\hline \multirow{2}{*}{$\begin{array}{c}\text { Bad oral } \\
\text { habits }\end{array}$} & $\begin{array}{c}\text { Tidak } \\
\text { ada }\end{array}$ & Ada & Total & $\begin{array}{c}\text { Sig. }(\boldsymbol{p} \text { - } \\
\text { value })\end{array}$ \\
\hline $\begin{array}{c}\text { Tidak } \\
\text { ada }\end{array}$ & 7 & 2 & 9 & 0,008 \\
$\begin{array}{c}\text { Ada } \\
\text { Total }\end{array}$ & 4 & 13 & 17 & \\
\hline
\end{tabular}

Tabel 5 menunjukkan hasil uji chi square pengaruh kebiasaan buruk oral 
terhadap malrelasi gigi pada anak panti asuhan usia 7-13 tahun di Panti Asuhan Nurul Haq dengan p-value sebesar 0,008 $(\mathrm{p}<0,05)$ yang artinya terdapat pengaruh kebiasaan buruk oral terhadap malrelasi gigi pada anak panti asuhan usia 7-13 tahun.

\section{PEMBAHASAN}

Sebanyak 26 anak di panti asuhan Nurul Haq Wonocatur, Kecamatan Banguntapan, Kabupaten Bantul, Yogyakarta dilibatkan dalam penelitian ini. Hasil penelitian menunjukkan bahwa prevalensi kebiasaan buruk oral yang terjadi pada usia 7-13 tahun sebanyak 18 anak $(69,1 \%)$ dengan kebiasaan mengisap ibu jari menjadi prevalensi tertinggi sebanyak tujuh anak $(26,9 \%)$ dan prevalensi terendah adalah kebiasaan bernapas melalui mulut sebanyak satu anak $(3,8 \%)$. Hasil penelitian ini sejalan dengan penelitian pada anak panti asuhan usia 4-12 tahun di Riyadh, Saudi Arabia yang menyatakan bahwa prevalensi mengisap ibu jari menjadi kebiasaan buruk oral yang paling banyak dilakukan oleh anak-anak yaitu sebanyak $53(58,9 \%)$ yang kemudian diikuti dengan kebiasaan oral self mutilation pada urutan kedua. $\underline{10}$

Kebiasaan mengisap ibu jari $(26,9 \%)$ dalam penelitian ini menunjukkan adanya kondisi protrusif, gigitan dalam, gigitan silang dan gigitan terbuka posterior. Gambaran klinis gigitan dalam akibat mengisap ibu jari tersaji pada gambar 1 . Hasil ini berbeda dengan teori menurut Premkumar (2014) bahwa kebiasaan mengisap ibu jari dapat menyebabkan gigitan terbuka anterior, perubahan bentuk wajah dan konstriksi maksila/penyempitan rahang atas. $\stackrel{8}{ }$ Peningkatan angka kebiasaan mengisap ibu jari khususnya pada anak panti asuhan dikarenakan banyaknya anakanak tidak mendapatkan ASI yang cukup, dimana pemberian ASI secara langsung dapat memberikan kenyamanan pada anak. Hal ini yang menyebabkan anak-anak kehilangan perasaan aman dan nyaman yang berasal dari orang tua terkhusus ibu, dan mengisap ibu jari merupakan kebiasaan yang dapat mengalihkan keadaan tersebut serta dapat memberikan perasaan nyaman. Beberapa situasi lain seperti kelaparan dan ketakutan dapat menstimulasi kebiasaan mengisap ibu jari pada anak-anak karena keadaan tersebut yang paling sering mereka rasakan..$\underline{10}$

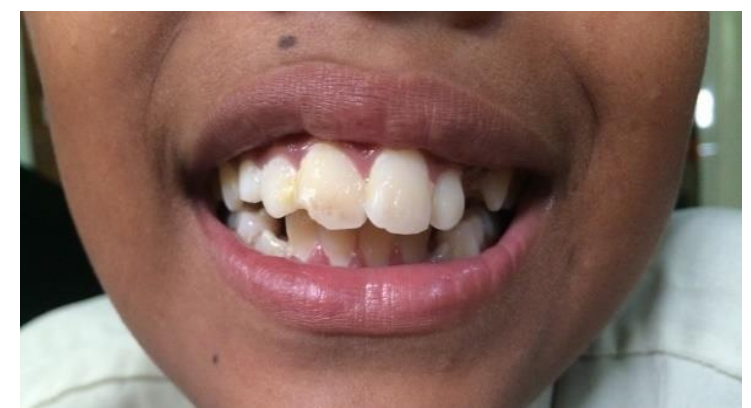

Gambar 1. Gambaran klinis gigitan dalam akibat mengisap ibu jari

Prevalensi tertinggi kedua pada penelitian ini adalah kebiasaan menggigit jari sebanyak tiga anak (11,5\%). Penelitian ini menunjukkan anak-anak yang melakukan kebiasaan tersebut mengalami gigitan terbuka posterior. Gambaran klinis gigitan terbuka akibat menggigit jari tersaji pada gambar 2. Hasil ini tidak sejalan dengan teori menurut Joelijanto (2012) bahwa anak yang melakukan kebiasaan buruk oral berupa menggigit jari akan mengalami maloklusi jenis protrusif. $\underline{11}$ Perbedaan ini mungkin disebabkan karena kebiasaan mengisap bibir pasti menyebabkan maloklusi tetapi tergantung pada intensitas, frekuensi dan durasi yang adekuat..

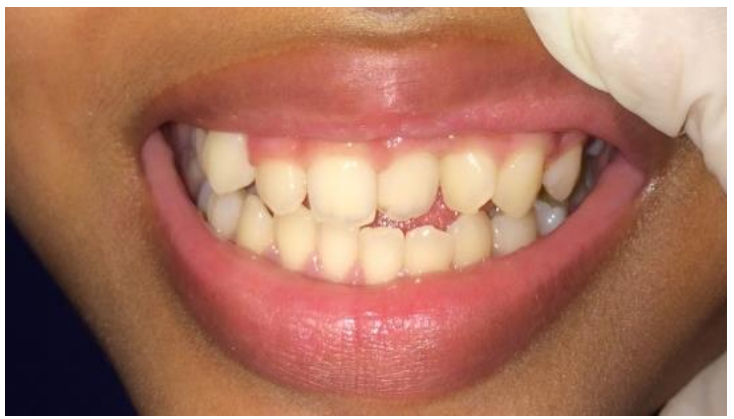

Gambar 2. Gambaran klinis gigitan terbuka akibat menggigit jari

$\begin{array}{cr}\text { Kebiasaan bruxism } & (7,7 \%) \\ \text { menyebabkan adanya atrisi gigi yang }\end{array}$


disertai dengan gigitan dalam dan protrusif. Gambaran klinis gigi akibat bruxism tersaji pada gambar 3. Hal ini sejalan dengan teori menurut Premkumar (2014) bahwa kebiasaan buruk bruxism apabila terjadi secara terus menerus dapat menyebabkan atrisi gigi, namun tidak disertai dengan penyakit periodontal, sakit kepala, dan temporomandibular dysfunction. ${ }^{-}$Kebiasaan ini biasanya dilakukan pada saat tidur di malam hari dan mereka tidak menyadari bahwa mereka memiliki kebiasaan buruk. Kebiasaan ini terkadang timbul pada masa perkembangan gigi dan dapat disebabkan karena adanya stres, amarah, sakit, atau bahkan frustasi. $\frac{12}{}$

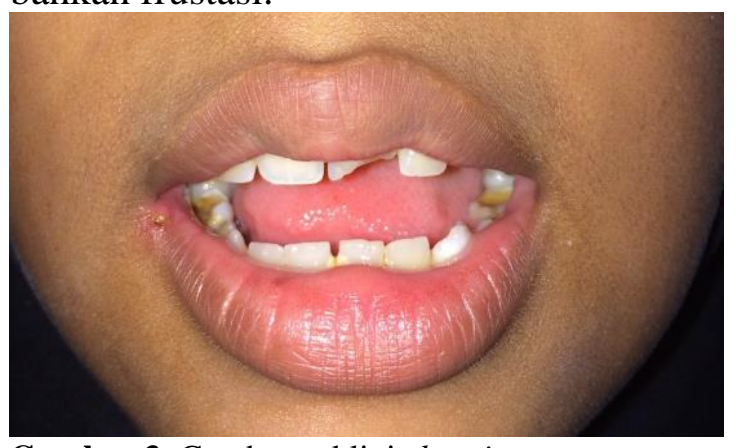

Gambar 3. Gambaran klinis bruxism

Kebiasaan menggigit bibir $(7,7 \%)$ menyebabkan protrusif dan malposisi gigigeligi. Hal ini sejalan dengan teori menurut Premkumar (2014), bahwa kebiasaan buruk menggigit bibir (lip habit/lip sucking) yang terjadi pada usia gigi bercampur akan menyebabkan proklinasi gigi seri rahang atas, namun tidak menunjukkan adanya retroklinasi gigi dan meningkatnya overjet. ${ }^{-}$ Kebiasaan bernapas dengan mulut $(3,8 \%)$ dalam penelitian ini tidak menunjukkan adanya malrelasi jenis apapun pada responden. Kebiasaan ini biasanya disebabkan oleh adanya gangguan pada jalan napas atau hidung berupa sumbatan, seperti pembesaran tonsil di belakang hidung, adanya polip hidung, serta pada beberapa orang mengalami lemah tonus pada bibir atas. $\underline{13}$

Dampak yang ditimbulkan oleh masing-masing jenis kebiasaan buruk oral tidak seluruhnya sesuai dengan teori yang ada atau bahkan penelitian yang sudah pernah dilakukan. Hal ini dapat terjadi dikarenakan intensitas, frekuensi dan durasi yang dilakukan tiap anak berbeda. Faktor emosional dan psikologis pasien turut berpengaruh dalam keparahan kebiasaan buruk oral. $\stackrel{14}{ }$ Hasil penelitian ini juga menunjukkan bahwa pengaruh dari kebiasaan buruk oral yang dilakukan oleh anak-anak tidak semua menunjukkan adanya malrelasi, contohnya terdapat dua anak yang memiliki palatum tinggi dikarenakan kebiasaan buruk oral mengisap ibu jari dan prolonged bottle feeding. Hal ini sejalan dengan hasil penelitian yang dikemukakan oleh Nabila dkk. (2017) bahwa kebiasaan buruk oral yang masih terus berlanjut setelah usia enam tahun dapat menyebabkan kelainan pada struktur dento-fasial seperti maloklusi, kelainan pada bentuk wajah, dan kelainan pada bentuk palatum. $\underline{3}$

Hubungan antara kebiasaan buruk oral dan maloklusi juga dipengaruhi oleh lamanya kebiasaan tersebut terjadi. Kedua variabel ini akan saling berhubungan apabila kebiasaan buruk oral sudah terjadi lebih dari tiga tahun. Kebiasaan buruk oral sebenarnya dapat terjadi untuk sementara waktu, namun apabil terus berlanjut maka dapat menyebabkan kesehatan gigi yang buruk hingga maloklusi. ${ }^{7}$ Kebiasaan buruk oral yang tidak segera ditangani pun dapat berdampak pada gangguan sistem stomatognasi. $\frac{15}{15}$

\section{KESIMPULAN}

Berdasarkan hasil penelitian yang dilakukan dapat disimpulkan bahwa terdapat pengaruh kebiasaan buruk oral terhadap malrelasi gigi pada anak Panti Asuhan Nurul Haq Yogyakarta usia 7-13 tahun. Kebiasaan buruk oral yang paling banyak terjadi adalah mengisap ibu jari.

\section{DAFTAR PUSTAKA}

1. Achmad MH, Natsir M, Samad R, Setijanto RD. 2016. Buku Saku Maloklusi Pada Anak Dan Penangannanya. 1st ed. Jakarta: Sagung Seto. 
2. Kamdar RJ, Al-Shahrani I. Damaging Oral Habits. JIOH. 2015;7(4):85-87.

3. Nabila RC, Primarti RS, Ahmad I. Hubungan Pengetahuan Orang Tua Dengan Kondisi Maloklusi Pada Anak Yang Memiliki Kebiasaan Buruk Oral. J Syiah Kuala Dent Soc. 2017;2(1):1218.

4. Elianora D. Perawatan Kebiasaan Buruk Mengisap Ibu Jari (Thumb Sucking) Dengan Alat Orto Trainer. Cakradonya Dent J. 2015;7(1):745806.

5. Susanto HC, Anggaraeni PI, Pertiwi NKF. Gambaran Kebiasaan Buruk Dan Kejadian Maloklusi Pada Siswa Sekolah Dasar Negeri 19 Pemecutan. BDJ.2019;3(1):29-33. https://doi.org/10.37466/bdj.v3i1.135

6. Septuaginta AA, Kepel BJ, Anindita PS. Gambaran Oral Habit Pada Murid SD Katolik II St. Antonius Palu. $e G$. 2013;1(1):18-27. https://doi.org/10.35790/eg.1.1.2013.1 $\underline{925}$

7. Giugliano D, Apuzzo F, Jamilian A, Perillo L. Relationship between Malocclusion and Oral Habits. Current Research in Dentistry. 2014;5(2):1721.

https://doi.org/10.3844/crdsp.2014.17. $\underline{21}$

8. Premkumar S. 2014. Manual of Pediatric Dentistry. 1st ed. New Delhi: Jaypee Brothers Medical Publishers.

9. Oliveira AC, Pordeus IA, Torres CS, Martins MT, Paiva SM. Feeding and nonnutritive sucking habits and prevalence of open bite and crossbite in children/adolescents with Down syndrome. The Angle Orthodontist. 2010;80(4):748-753. https://doi.org/10.2319/072709-421.1

10. AlSadhan SA, Al-Jobair AM. Oral habits, dental trauma, and occlusal characteristics among 4- to 12-year-old institutionalized orphan children in
Riyadh, Saudi Arabia. Spec Care Dentist.2017;37(1):10-18.

$10.1111 / \mathrm{scd} .12187$

11. Joelijanto R. Oral Habits That Cause Malocclusion Problems. IDJ. 2012;1(2). https://doi.org/10.18196/di.v1i2.536

12. Shah AF, Batra M, CB S, Gupta M, Kumar R, Kadambariambildhok. Oral Habits And Their Implications. Ann Med. 2014;1(4):179-186.

13. Christensen JR, Fields HW, Adair SM. 2013. Oral Habits. In: Pediatric Dentistry: Infancy Through Adolescence. 5th ed. St. Louis: Elsevier Saunders.

14. Leme MS, Barbosa $\mathrm{T}$ de S, Gavião MBD. Relationship among oral habits, orofacial function and oral healthrelated quality of life in children. $\mathrm{Braz}$ Oral Rez. 2013;27(3):272-278. https://doi.org/10.1590/S180683242013000300006

15. Motta LJ, Alfaya TA, Marangoni AF, Mesquita-Ferrari RA, Fernandes KPS, Bussadori SK. Gender as risk factor for mouth breathing and other harmful oral habits in preschoolers. Braz J Oral Sci. 2012;11(3):377-380. https://doi.org/10.20396/bjos.v11i3.86 $\underline{41374}$ 